\title{
Sprawozdanie z konferencji International Neuropsychological Society (Praga, Czechy, 18-20 lipca 2018 r.)
}

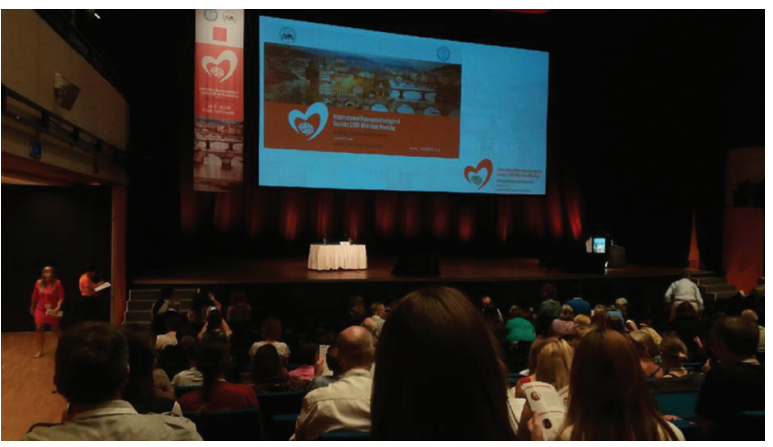

W lipcu 2018 roku na terenie Praskiego Centrum Kongresowego nieopodal Wełtawy odbyła się kolejna konferencja INS (International Neuropsychological Society). W organizacji tej edycji uczestniczyli przedstawiciele INS, Czeskiego Towarzystwa Neuropsychologicznego i Czeskiego Towarzystwa Neurologicznego, a patronat nad wydarzeniem objęły: Ministerstwo Zdrowia Republiki Czeskiej, Ministerstwo Szkolnictwa, Młodzieży i Sportu Republiki Czeskiej, Ministerstwo Rozwoju Regionalnego Republiki Czeskiej oraz władze Uniwersytetu Karola w Pradze.

INS jest organizacją non profit skupiającą profesjonalistów z różnych dziedzin nauki i praktyki, a celami jej działań są promowanie współpracy międzynarodowej w badaniach relacji mózg - zachowanie oraz aplikacja wyników badań w rozmaitych obszarach, takich jak edukacja, medycyna czy rehabilitacja. Służą temu organizowane dwa razy w roku konferencje (najbliższa lada chwila odbędzie się w Rio de Janeiro).

Początek działalności INS datuje się na rok 1967, a obecnie organizacja skupia ponad 4300 członków z kilkudziesięciu krajów. Powstanie INS poprzedzone było spotkaniami i wymianą doświadczeń naukowo-praktycznych w ramach lokalnych konferencji na terenie USA. Spotkania zaowocowały cyklicznymi publikacjami w „The Neuropsychology Bulletin” („The INS Bulletin”), aktualnie zaś oficjalnym czasopismem INS jest „Journal of the International Neuropsychological Society”. Kolejne wydania „INS Bulletin” sygnowali m.in. Karl Pribram, Harry Whitaker, Arthur Benton i Edith Kaplan. Na konferencji naukowej zorganizowanej wspólnie z American Psychological Association (APA) w 1967 roku (Waszyngton) pojawiła się idea utworzenia INS. Dyskutowano wówczas o konieczności wyróżnienia subdyscyplin - klinicznej czy eksperymentalnej - w ramach neuropsychologii, zajęto się również problematyką jej nauczania. W 1973 roku na konferencji w Nowym Orleanie uczestnicy podkreślili konieczność uwzględnienia w analizach neuropsychologicznych zagadnień, które dotychczas leżały w obszarze zainteresowań psychologii ogólnej lub edukacji, takich jak trudności dzieci w nauce, oraz kwestii nowych, takich jak asymetria funkcjonalna mózgu. Podczas kolejnych edycji dodawano problemy istotne z punktu widzenia medycyny: skutki urazów czaszkowo-mózgowych, afazje, zaburzenia pamięci. Formułowano główne założenia nauczania neuropsychologii, zaznaczając konieczność podnoszenia kwalifikacji osób specjalizujących się w tej dziedzinie. Wyznaczano też nowe obszary dyskusji, takie jak neuropsychologia i prawo, rehabilitacja funkcji poznawczych u osób z patologią mózgu, neurotransmitery a zachowanie, standardy metodologiczne w badaniach neuropsychologicznych, neurointoksykacje, starzenie się, plastyczność mózgu i wiele innych. O interdyscyplinarności INS świadczy udział osób reprezentujących różne dziedziny i dyscypliny: psychologię kliniczną, poznawczą, neuropsychologię, neurologię, neurochirurgię, psychiatrię czy fizjoterapię.

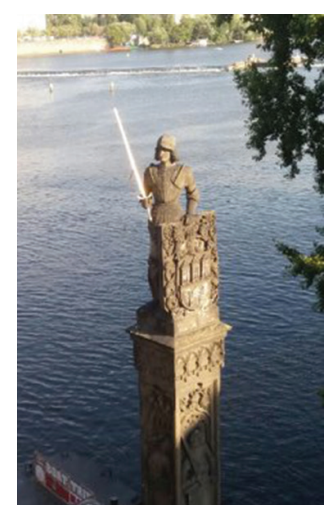


Z działalnością INS wiąże się aktywność wielu wybitnych neurologów i neuropsychologów, m.in. Barbary A. Wilson, Muriel Lezak, Kena Heilmana, Marcela Kinsbourne’a, Harolda Goodglassa, Paula Satza, Aleksandra Łurii, Normana Geschwinda i Mariusza Maruszewskiego, wybitnego polskiego neuropsychologa (Rourke i Murji, 2000). W 2010 roku jedna z edycji konferencji odbyła się w Krakowie. Obecnie funkcję prezydenta INS pełni prof. Keith O. Yeates, którego zainteresowania dotyczą

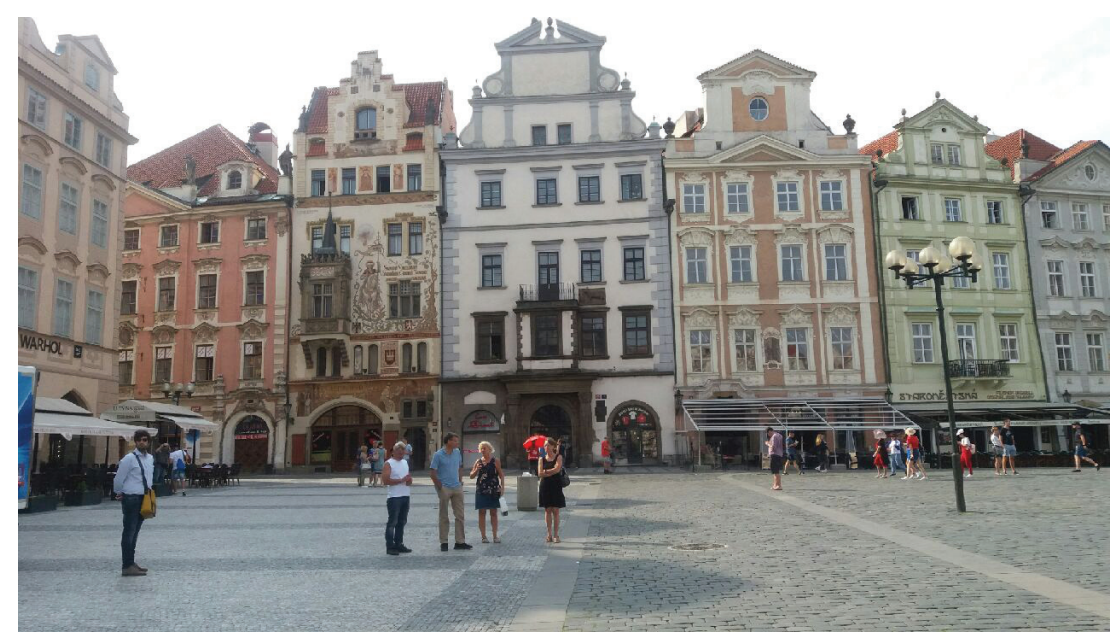
skutków urazów czaszkowo-mózgowych i innych schorzeń mózgowych u dzieci oraz rehabilitacji funkcji poznawczych i społecznych.

Od początku działalności INS akcentowano związek neuropsychologii z medycyną i konieczność rozwoju neuropsychologii na potrzeby medycyny. Tę zachętę do współpracy odzwierciedlało hasło ubiegłorocznej konferencji w Pradze: Bridging Science with Humanity.

Tematyka wykładów plenarnych koncentrowała się wokół najistotniejszych zagadnień neuropsychologii

klinicznej. Barbara A. Wilson wraz z zespołem omawiała rzadkie i nietypowe zaburzenia wywołane patologią układu nerwowego - ich objawy i dynamikę, Pozostałe wykłady plenarne dotyczyły neuropsychologicznych problemów chorych z nowotworami i padaczką czy związku środowiska kulturowego i rozwoju człowieka. Melissa Lamar zaprezentowała, jak wczesny rozwój warunkuje przebieg późniejszego starzenia się.

Wiele uwagi poświęcono problemom diagnozowania deficytów poznawczych u pacjentów z guzami mózgu, stwardnieniem rozsianym, schizofrenią, padaczką, po urazach czaszkowo-mózgowych oraz w przebiegu otępień (choroby Alzheimera i otępienia czołowo-skroniowego - frontotemporal dementia, FTD). Omawiano także mechanizmy i cechy kliniczne zespołu zamknięcia (locked-in syndrome), deficyty poznawcze i ich związki z parametrami klinicznymi u nosicieli wirusa HIV, osób po transplantacji nerki, z dystonią mięśniową, cukrzycą czy chorobą Parkinsona.

Podczas wykładów przedstawiano również rozmaite formy i metody rehabilitacji funkcji psychicznych. Omówione zostały programy (telehealth) przeznaczone dla pacjentów po udarze mózgu mieszkających daleko od dużych aglomeracji, umożliwiające usprawnianie m.in. pamięci, okulary pryzmatyczne $\mathrm{w}$ rehabilitacji chorych z zespołem pomijania stronnego, spersonifikowana wirtualna rzeczywistość dostosowana do indywidualnych potrzeb chorego po udarze oraz aplikacje (np. SMART $4 \mathrm{MD}$ ) dla osób z demencją i ich opiekunów. Dyskutowano ponadto o skuteczności technik neuromodulacji oraz neurofeedbacku.

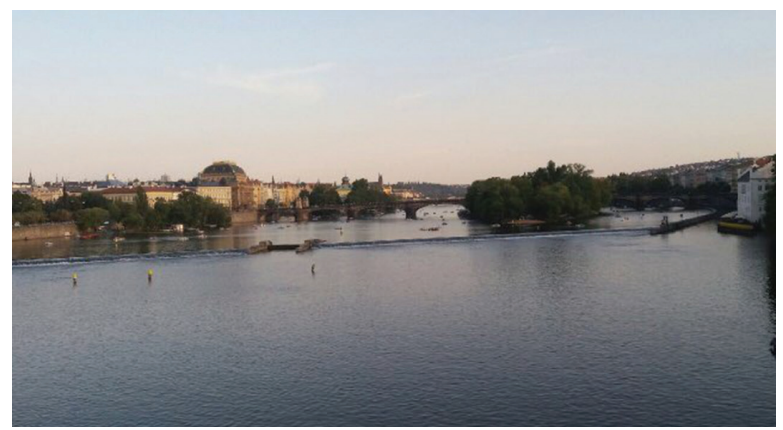

Starzenie się satysfakcjonujące i patologiczne było przedmiotem kilkunastu wystąpień i posterów. Rozważano związek między poczuciem trudności poznawczych (subjective cognitive decline) a rozwojem łagodnych zaburzeń poznawczych (mild cognitive impairment, MCI) i otępienia oraz wskaźnikami neuroobrazowymi. Na podstawie analiz funkcji językowych omówiono zróżnicowanie obrazu klinicznego w chorobie Alzheimera, otępieniu z ciałami Lewy'ego (dementia with Lewy bodies, DLB) i wariantach FTD.

Kolejnym tematem wystąpień były metody diagnostyczne - przedstawiono m.in. zrewidowane wersje Montrealskiej Skali Oceny Funkcji Poznawczych (Montreal Cognitive Assessment, MoCA) i adaptacje znanych testów neuropsychologicznych. Zdaniem prelegentów perspektywa międzykulturowa, uwzględniająca globalizację problemów neuropsychologicznych i zjawiska migracji, wymaga przygotowania skal/testów neuropsychologicznych o charakterze ponadkulturowym. 
W sesji dotyczącej neuropsychologii dzieci omawiano skutki urazów czaszkowo-mózgowych, a także specyfikę deficytów poznawczych u dzieci z zaburzeniami uczenia się i uwagi oraz zaburzeniami rozwoju językowego, niską wagą urodzeniową, torbielami pajęczynówki, wodogłowiem czy spektrum poalkoholowych zaburzeń rozwojowych (foetal alcohol spectrum disorder, FASD).

Wyniki badań prezentowano też w formie posterów (sześć sesji). Tematyka była różnorodna, a do najciekawszych należały studia przypadków chorych z encefalopatią manganową (manganese hepatic encephalopathy), opisy problemów klinicznych osób z fibromialgią i zaburzeniami snu oraz deficytów neuropsychologicznych u pacjentów z chorobą moyamoya.

Zarówno w ramach wykładów plenarnych, jak i sesji posterowych prezentowano dane neuroobrazowe dotyczące schorzeń mózgowych o zróżnicowanej etiologii. Przedstawiono przykładowo sieci neuronowe u pacjenta z czystą aleksją dotyczącą znaków kanji, funkcjonalne korelaty zespołu stresu pourazowego (posttraumatic stress disorder, PTSD) u dzieci, obrazowanie istoty białej u osób z poczuciem trudności poznawczych, obraz traktografii u pacjentów po urazach czaszkowo-mózgowych.

Poza bogatym programem naukowym i wymianą doświadczeń miłym akcentem konferencji było uhonorowanie prof. dr hab. Emilii Łojek (UW) nagrodą Paul Satz Mentoring Award - przyznawaną osobom, które w szczególny sposób przyczyniają się do rozwoju studentów i młodszych pracowników naukowych w dziedzinie neuropsychologii.

\section{Piśmiennictwo}

Rourke BP, Murji S: A history of the International Neuropsychological Society: the early years (1965-1985). J Int Neuropsychol Soc 2000; 6: 491-509. 